\title{
Purification, structure and immunobiological activity of an arabinan-rich pectic polysaccharide from the cell walls of Prunus dulcis seeds
}

\author{
Fernando Dourado, ${ }^{\mathrm{a}}$ Pedro Madureira, ${ }^{\mathrm{b}}$ Vera Carvalho, ${ }^{\mathrm{a}}$ Ricardo Coelho, ${ }^{\mathrm{f}}$ \\ Manuel A. Coimbra, ${ }^{c}$ Manuel Vilanova, ${ }^{\mathrm{d}, \mathrm{e}}$ Manuel Mota ${ }^{\mathrm{a}}$ and Francisco M. Gama ${ }^{\mathrm{a}, *}$ \\ ${ }^{a}$ Centro de Engenharia Biológica, Largo do Paço, Universidade do Minho, 4710-057 Braga, Portugal \\ ${ }^{\mathrm{b}}$ Instituto de Ciências Biomédicas Abel Salazar, Largo Prof. Abel Salazar, 2P-4099-003 Porto, Portugal \\ ${ }^{\mathrm{c}}$ Departamento de Química, Universidade de Aveiro, 3810-193 Aveiro, Portugal \\ ${ }^{\mathrm{d}}$ Instituto de Ciências Biomédicas Abel Salazar, Largo Prof. Abel Salazar, 2P-4099-003 Porto, Portugal \\ e IBMC-Instituto de Biologia Molecular e Celular, rua do Campo Alegre 823, 4150-180 Porto, Portugal \\ ${ }_{\mathrm{f}}^{\mathrm{f}}$ Instituto de Tecnologia Química e Biológica, Universidade Nova de Lisboa, Apartado 127, 2780 Oeiras, Portugal
}

Received 5 November 2003; accepted 28 July 2004

Available online 25 September 2004

\begin{abstract}
The structure and bioactivity of a polysaccharide extracted and purified from a $4 \mathrm{M} \mathrm{KOH}+\mathrm{H}_{3} \mathrm{BO}_{3}$ solution from Prunus dulcis seed cell wall material was studied. Anion-exchange chromatography of the crude extract yielded two sugar-rich fractions: one neutral (A), the other acidic (E). These fractions contain a very similar monosaccharide composition: 5:2:1 for arabinose, uronic acids and xylose, respectively, rhamnose and galactose being present in smaller amounts. As estimated by size-exclusion chromatography, the acidic fraction had an apparent molecular mass of $762 \mathrm{kDa}$. Methylation analysis (from the crude and fractions A and E), suggests that the polysaccharide is an arabinan-rich pectin. In all cases, the polysaccharides bear the same type of structural Ara moieties with highly branched arabinan-rich pectic polysaccharides. The average relative proportions of the arabinosyl linkages is

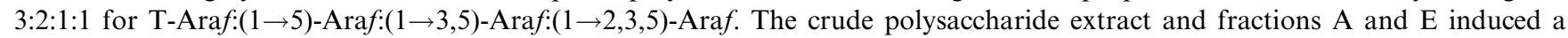
murine lymphocyte stimulatory effect, as evaluated by the in vitro and in vivo expression of lymphocyte activation markers and spleen mononuclear cells culture proliferation. The lymphocyte stimulatory effect was stronger on B- than on T-cells. No evidence of cytotoxic effects induced by the polysaccharide fractions was found.
\end{abstract}

(C) 2004 Elsevier Ltd. All rights reserved.

Keywords: Prunus dulcis; Seeds; Polysaccharides; Arabinan; Xylan; Methylation analysis; Immunobiological activity

\section{Introduction}

From birth, living systems are continually exposed to a variety of microorganisms that have the potential to cause disease and death. In vertebrates, protection from pathogenic microorganisms is achieved by a complex array of defensive mechanisms collectively termed the immune system. ${ }^{1,2}$ These same immune mechanisms, which efficiently eliminate pathogens, pose a potential threat to

\footnotetext{
* Corresponding author. Tel.: +351253 604400; fax: +351 253678986 ; e-mail: fmgama@deb.uminho.pt
}

the host that must thus ensure immune tolerance to the somatic self. ${ }^{3}$ When immune control mechanisms fail, infectious or autoimmune pathology ensues, and agents capable of improving defence or regulatory immune responses are potentially helpful. Compounds that are capable of interacting with the immune system to upregulate or downregulate specific aspects of the host response can be classified as immunomodulators or biologic response modifiers. ${ }^{4}$

In recent years, plant polysaccharides have emerged as an important class of bioactive natural products. A wide range of polysaccharides has been reported to exhibit a variety of immunological activities: anti-tumour, ${ }^{5}$ 
immunostimulatory, ${ }^{6-9}$ anti-complementary, ${ }^{10-12}$ antiinflammatory, ${ }^{13}$ anti-coagulant and fibrinogenic. ${ }^{14}$

Almond seeds are typically used in a variety of processed foods, notably in bakery and confectionery products. ${ }^{15}$ With $16-22 \%$ (w/w, dry weight) protein, except for methionine, almonds contain all the essential amino acids ( $\mathrm{g}$ essential aminoacids/ $100 \mathrm{~g}$ protein) in quantities equal or greater than those recommended by the FAO guidelines. ${ }^{16,17}$ The seed's high oil content (around $50 \%, w / w)$, with oleic and linoleic acids as the major constituents, ${ }^{18,19}$ makes it a valuable product in the human diet and cosmetics.

This paper describes the isolation and structural characterisation of an arabinan-rich pectic polysaccharide obtained from the Prunus dulcis cell wall material (CWM) by extraction with a $4 \mathrm{M} \mathrm{KOH}+\mathrm{H}_{3} \mathrm{BO}_{3}$ solution. Moreover, based on previously reported evidence of immune activities of polysaccharides of microbial (reviewed in Ref. 4) or plant origin, ${ }^{20-28}$ a possible immunomodulatory effect of the arabinan-rich pectin was studied in murine models.

\section{Experimental}

A mixture containing several regional varieties (Bojuda, Ferradouro, Fôfana, Grada, José Dias, Ludo, Molar da Fuseta) of dehulled almond seeds was supplied from the region of Alfândega da Fé (Bragança, Portugal). The cell-wall material (CWM) was prepared and sequentially extracted with imidazole, $\mathrm{Na}_{2} \mathrm{CO}_{3}$ and $\mathrm{KOH}$ solutions $\left(0.5\right.$ and $1 \mathrm{M}$ at $4{ }^{\circ} \mathrm{C}, 1,4 \mathrm{M}, 4 \mathrm{M}+\mathrm{H}_{3} \mathrm{BO}_{3}, 8 \mathrm{M}$ at $20^{\circ} \mathrm{C}$ ) as described in Dourado et al. ${ }^{29}$ The crude extract from the $4 \mathrm{M} \mathrm{KOH}+\mathrm{H}_{3} \mathrm{BO}_{3}$ treatment was used in the present work. Preliminary immunobiological activity assays were conducted with the crude extract. This extract exhibited a lymphocyte stimulatory activity and was thus further purified and characterised in the present work.

\subsection{Isolation and structure characterisation of a poly- saccharide from almond CWM}

2.1.1. Anion-exchange chromatography. The crude extract $(1 \mathrm{~g})$ was dissolved overnight in $1 \mathrm{~L}$ of $0.1 \mathrm{M}$ $\mathrm{NaOH}$, at room temperature. The solution was passed through a $50 \times 460$-mm DEAE Sepharose Fast Flow packed column $(2.7 \mu \mathrm{mol}$ uronic acid $/ \mathrm{mL}$ resin $)$ in the chloride form, at a flow rate of $0.7 \mathrm{~mL} / \mathrm{min}$. The neutral polysaccharides were eluted at room temperature with a $0.1 \mathrm{M} \mathrm{NaOH}$ solution $(1.5 \mathrm{~L})$ and the acidic fractions were eluted with a linear gradient of $\mathrm{NaCl}(0-1 \mathrm{M}$ in the same alkaline solution; $1.5 \mathrm{~L}$ ).

Fractions of $10 \mathrm{~mL}$ were collected and assayed for total carbohydrates by the phenol- $\mathrm{H}_{2} \mathrm{SO}_{4}$ method. ${ }^{30}$ The sugar-rich fractions (A, B, C, D, E; Fig. 1) were pooled, dialysed against distilled water and freeze dried.

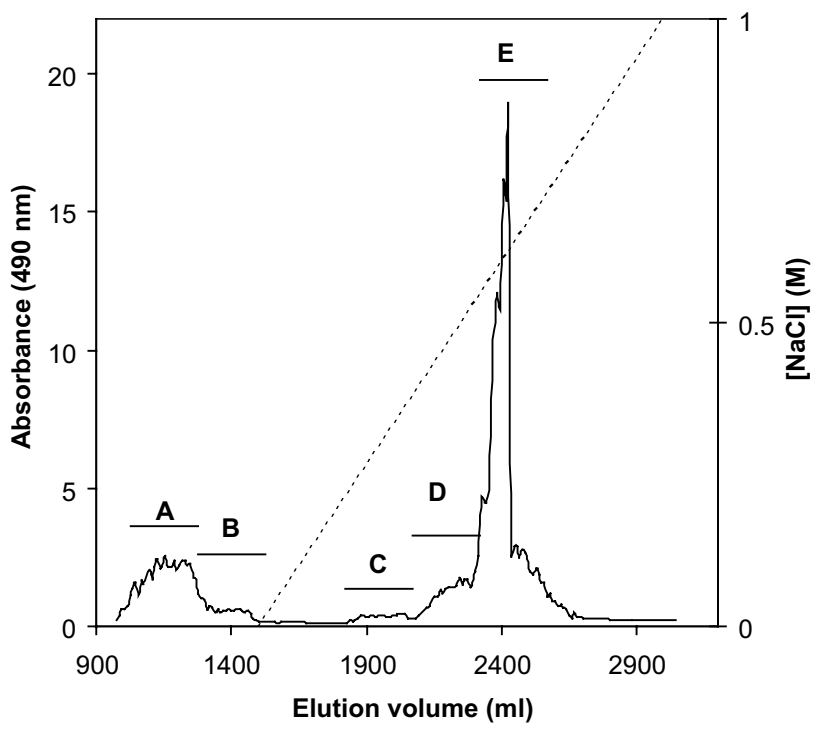

Figure 1. Elution profile of the crude extract on DEAE Sepharose Fast Flow. The crude extract $(1 \mathrm{~g})$ was dissolved overnight in $1 \mathrm{~L} 0.1 \mathrm{M}$ $\mathrm{NaOH}$ and applied to the column. Neutral polysaccharides where eluted with $0.1 \mathrm{M} \mathrm{NaOH}$, and the acidic fractions were eluted with a linear gradient of $\mathrm{NaCl}(0-1 \mathrm{M}$ in the same alkaline solution). Fractions were collected and monitored by the phenol- $\mathrm{H}_{2} \mathrm{SO}_{4}$ method. (-) Total carbohydrates; (---) $\mathrm{NaCl}$ gradient.

2.1.2. Elemental analysis. The crude extract and fractions $\mathrm{A}$ and $\mathrm{E}$ were tested for nitrogen $(\mathrm{N})$ contamination, by the ICP (Inductively Coupled Plasma) technique and by LSM (Light Scanning Microscopy). ICP was done at IAREN-Instituto da Água da Região do Norte (Portugal) using a Varian model Liberty AX.

LSM was done using a Leica Cambrigge S-360 coupled with a Microanalysis System by energy dispersion spectrometry (EDX)-Link eXL II. Samples were covered with gold by magnetron sputtering.

In all fractions analysed, nitrogen was not detected by these two methods.

2.1.3. Size-exclusion chromatography. The crude extract, fractions $\mathrm{A}$ and $\mathrm{E}(500 \mu \mathrm{L}$, at a concentration of $1 \mathrm{mg} / \mathrm{mL}$ ) were injected into a $9 \times 500 \mathrm{~mm}$ Sephacryl S-400 HR packed column (the useful fractionation range for dextrans is $10-2000 \mathrm{kDa}$, according to Pharmacia-Biotech). Size exclusion was run with a flow rate of $0.7 \mathrm{~mL} / \mathrm{min}$, at room temperature, using $0.1 \mathrm{M} \mathrm{NaOH}$ as eluent. Fractions of $1.5 \mathrm{~mL}$ were collected and analysed for total carbohydrates by the phenol- $\mathrm{H}_{2} \mathrm{SO}_{4}$ method. ${ }^{30}$

Calibration of the column was done using dextran standards (all from Sigma) with average molecular masses of $10,40,70,526 \mathrm{kDa}$. The void volume was estimated with Blue Dextran (2000kDa).

2.1.4. Dynamic light scattering. Samples from fraction $\mathrm{A}$ and $\mathrm{E}(1 \mathrm{mg} / \mathrm{mL}$, weighted) were dissolved in water 
and $0.1 \mathrm{M} \mathrm{NaOH}$. The samples were centrifuged for $5 \mathrm{~min}$ at $10,000 \mathrm{~g}$ and analysed with a Protein Solutions Dynapro MS instrument using the DINAMICS software. Calibration was done using dextran standards (all from Sigma) with average molecular masses of $10,40,70$, $526 \mathrm{kDa}$.

\subsubsection{Quantitative determination of monosaccharides and} uronic acids. Neutral sugars, released by Saeman hydrolysis, ${ }^{31}$ were analysed as their alditol acetates by gas-liquid chromatography in a Carlo Erba GC 6000 series 2, with a FID detector and a DB 225 column. The injector and detector temperature were at 220 and $230^{\circ} \mathrm{C}$, respectively. Following injection (approximately $2 \mu \mathrm{L}$ ) of the sample, the oven was maintained at $220^{\circ} \mathrm{C}$ for $5 \mathrm{~min}$, followed by a temperature rise of $5^{\circ} \mathrm{Cmin}{ }^{-1}$, until $230^{\circ} \mathrm{C}$. This temperature was maintained for $6 \mathrm{~min}$. Hydrogen was used as a carrier gas at $78 \mathrm{~Pa}$, and 2deoxy-glucose (2-deoxy-D-arabinose-hexose) was used as internal standard.

Methylation and carboxyl reduction of the polysaccharides from the crude extract and from fractions $\mathrm{A}$ and $\mathrm{E}$ was carried out following the Ciucanu and Kerek, ${ }^{32}$ Isogai et al. ${ }^{33}$ and Lindberg and Lönngren ${ }^{34}$ procedures, as described by Coimbra et al. ${ }^{35}$

2.1.6. Methylation procedure. The sample $(2-3 \mathrm{mg})$ was weighed into glass tubes and placed in a vacuum oven, at $40^{\circ} \mathrm{C}$, overnight in the presence of $\mathrm{P}_{2} \mathrm{O}_{5}$ (s). Afterwards it was dispersed in $2 \mathrm{~mL}$ of anhyd $\mathrm{Me}_{2} \mathrm{SO}$ and sonicated occasionally until it was fully dispersed. $\mathrm{NaOH}$ pellets $(100 \mathrm{mg})$ powdered under argon were added to the solution. The sample was sonicated for $90 \mathrm{~min}$ and allowed to stand for another $90 \mathrm{~min}$. The solution was cooled in an ice bath, and then $1 \mathrm{~mL}$ of cold methyl iodide was added. The mixture was allowed to react for $30 \mathrm{~min}$ in an ultrasonic bath and left standing for another $30 \mathrm{~min}$. Three $\mathrm{mL}$ of $1: 1 \mathrm{CHCl}_{3}-\mathrm{MeOH}$ were added, and the solution was dialysed against three lots of $50 \%$ EtOH. The material was then evaporated and freeze dried.

This methylation procedure was repeated, and the resulting material was dialysed. The solution obtained was divided ( $2 / 3$ of which was used for the reduction of the carboxyl reduction of the methylated polysaccharides) and freeze dried.

\subsubsection{Hydrolysis, reduction and acetylation of the meth-} ylated polysaccharides. The methylated polysaccharides were hydrolysed with $300 \mu \mathrm{L}$ of $2 \mathrm{M}$ TFA, at $121^{\circ} \mathrm{C}$, for $1 \mathrm{~h},{ }^{36}$ cooled and evaporated. The methylated sugars were then suspended in $200 \mu \mathrm{L}$ of $2 \mathrm{M} \mathrm{NH}_{3}$, and $20 \mathrm{mg} \mathrm{NaBD}{ }_{4}$ were added. The mixture was left reacting at $30^{\circ} \mathrm{C}$ for $1 \mathrm{~h}$. The reaction was terminated by the addition of $0.1 \mathrm{~mL}$ of glacial HOAc. The acetylation was done by adding $450 \mu \mathrm{L}$ of 1 -methylimidazole and
$3 \mathrm{~mL}$ of $\mathrm{Ac}_{2} \mathrm{O}$ and allowing the mixture to react for $30 \mathrm{~min}$, at $30^{\circ} \mathrm{C}$. Then, $3 \mathrm{~mL}$ of distilled water were added to decompose the $\mathrm{Ac}_{2} \mathrm{O}$, and the acetylated sugars were extracted with $3-5 \mathrm{~mL}$ of $\mathrm{CH}_{2} \mathrm{Cl}_{2}$. The organic phase was washed three times with water and then evaporated to dryness.

\subsubsection{Carboxyl reduction of methylated polysacchar-} ides. To the freeze-dried methylated material, $20 \mathrm{mg}$ of $\mathrm{LiAlD}_{4}$ and $1 \mathrm{~mL}$ anhyd THF were added and the mixture was left to react for $4 \mathrm{~h}$, at $65^{\circ} \mathrm{C}$. The reagent in excess was eliminated by adding 2-3 drops of EtOH and 2-3 drops of distilled water. The $\mathrm{pH}$ of the mixture was reduced to neutrality by adding $2 \mathrm{M} \mathrm{H}_{3} \mathrm{PO}_{4}$. Two $\mathrm{mL}$ of $2: 1 \mathrm{CHCl}_{3}-\mathrm{MeOH}$ mixture were then added. The reduced polymers were removed from the white precipitate by centrifugation and washed thoroughly with $2: 1 \mathrm{CHCl}_{3}-\mathrm{MeOH}$. The supernatant collected was evaporated, and the carboxyl-reduced material was submitted to hydrolysis, reduction and acetylation, as described above.

The partially methylated alditol acetates (PMAA) were dissolved in $70 \mu \mathrm{L}$ of $\mathrm{CH}_{2} \mathrm{Cl}_{2}$, analysed by $\mathrm{GC}-$ FID using a DB-1 capillary column, and characterised by GC-MS. The samples were injected in the splitless mode (time of splitless $0.75 \mathrm{~min}$ ), with the injector and detector at 220 and $230{ }^{\circ} \mathrm{C}$, respectively. The following temperature program was used: $45^{\circ} \mathrm{C}$ for 1 min with a linear increase of $45^{\circ} \mathrm{Cmin}^{-1}$ up to $140^{\circ} \mathrm{C}$, and standing for $1 \mathrm{~min}$ at this temperature, followed by a linear increase of $0.5^{\circ} \mathrm{Cmin}^{-1}$ up to $170^{\circ} \mathrm{C}$, with $1 \mathrm{~min}$ further at $170^{\circ} \mathrm{C}$. Then, another linear increase of $45^{\circ} \mathrm{Cmin}^{-1}$ up to $220^{\circ} \mathrm{C}$, and standing for $5 \mathrm{~min}$ at this temperature.

The linear velocity of the $\mathrm{H}_{2}$ carrier gas was set at $50 \mathrm{~cm} / \mathrm{s}$ at $218^{\circ} \mathrm{C}$. The molar response factors of Sweet et al. $^{37}$ were used for the quantification of the resolved sugars.

GC-MS analysis was done on a Finigan Trace 2000 Series Chromatograph (Thermoquest CE Instruments) equipped with a Finigan Trace MS. The chromatographic conditions used were as described for GCFID. The linear velocity of the He carrier gas was set at $1.8 \mathrm{~mL} / \mathrm{min}$ at $200^{\circ} \mathrm{C}$, with a solvent delay of $4 \mathrm{~min}$.

\subsection{Immunobiologic activity assay}

2.2.1. Preparation of the polysaccharide extract. The crude cell-wall extract obtained from the $4 \mathrm{M}$ $\mathrm{KOH}+\mathrm{H}_{3} \mathrm{BO}_{3}$ treatment and the fractions $\mathrm{A}$ and $\mathrm{E}$, obtained by anion-exchange chromatography, were used for the assays. The solutions (ca. $1 \mathrm{mg} / \mathrm{mL}$, weighed) were prepared by dispersing the polysaccharides in $50 \mathrm{mM}$ Tris- $\mathrm{HCl}$ Buffer $+1 \mathrm{M} \mathrm{NaCl}$. These samples were then sterilised by filtering through a $0.22-\mu \mathrm{m}$ filter (Whatman), and aliquots were collected and assayed for total carbohydrates by the phenol- $\mathrm{H}_{2} \mathrm{SO}_{4}$ method. ${ }^{30}$ 
For removal of any contaminant bacterial lipopolysaccharide (LPS), the filtered solutions were, under sterile conditions, passed through a 5-mL Detoxigel column (Pierce), previously washed several times with endotoxin-free water $(25 \mathrm{~mL}), 1 \%(\mathrm{w} / \mathrm{v})$ deoxicolic acid solution $(25 \mathrm{~mL})$, and then equilibrated with a solution containing $50 \mathrm{mM}$ Tris $-\mathrm{HCl}$ Buffer $+1 \mathrm{M} \mathrm{NaCl}$. The solutions were finally concentrated and washed several times with endotoxin-free Phosphate Buffered Saline (PBS) in an ultrafiltration device (Centriplus, Amicon Bioseparations, Millipore), to exchange buffers. Total carbohydrates were also determined before and following buffer exchange in order to estimate the loss of polysaccharide. No losses were detected following column passage and buffer exchange.

2.2.2. Mice. Male C57BL/6 mice (6-8 weeks old) were purchased from Charles River (Barcelona, Spain), and male C57BL/B10 ScCr mice (also 6-8 weeks old) were obtained from the Instituto Gulbenkian de Ciência (Oeiras, Portugal). All mice were kept at the animal facilities of the Institute Abel Salazar, under specific pathogen-free conditions until used. Sterile food and water were supplied ad libitum.

2.2.3. In vitro mononuclear cell cultures of murine mononuclear spleen cells. Spleen cells were obtained by gently teasing the organ in RPMI-1640 medium (Sigma, St. Louis, USA) supplemented with penicillin $(100 \mathrm{IU} / \mathrm{mL})$, streptomycin $(50 \mu \mathrm{g} / \mathrm{mL}), 2$-mercaptoethanol $(0.05 \mathrm{M})$ and $10 \%$ of fetal bovine serum (Sigma, St. Louis, USA) (RPMI) with or without $50 \mu \mathrm{g} / \mathrm{mL}$ of polymixin B (Sigma, St. Louis, USA). To isolate mononuclear cells, $5-\mathrm{mL}$ aliquots of the spleencell suspensions were layered onto $2.5-\mathrm{mL}$ aliquots of a polysucrose/sodium ditrizoate solution (histopaque1083, Sigma Diagnostics, St. Louis, USA) and centrifuged at $110 \mathrm{~g}$ for $20 \mathrm{~min}$, at room temperature. Cells were then gently removed from the medium/histopaque interface and then transferred to a sterile container and washed with RPMI. Finally, the isolated mononuclear cells were resuspended in $5 \mathrm{~mL}$ of RPMI, and cell counts were performed.

Mononuclear cell suspensions were distributed on 96well plates $\left(5 \times 10^{5}\right.$ cells/well $)$ and cultured for $6 \mathrm{~h}$ or 3 days at $37^{\circ} \mathrm{C}$, in a $95 \%$ humidified atmosphere containing $5 \% \mathrm{CO}_{2}$. Plated cells were stimulated with medium alone (negative control), $5 \mu \mathrm{g} / \mathrm{mL}$ of LPS from Salmonella abortus equi (Sigma, St. Louis), $5 \mu \mathrm{g} / \mathrm{mL}$ of concanavalin A (Sigma St. Louis) (Positive controls) or with $250 \mu \mathrm{g} / \mathrm{mL}$ of either crude extract, or fractions A or E.

2.2.4. In vitro proliferation assays. In order to evaluate polysaccharide-induced proliferation on mononuclear cell cultures, the 'MTT proliferation assay' was used.
At the end of the incubation period, cell-culture supernatants were replaced by an equal volume of an MTT (methylthiazoletetrazolium; Sigma, St. Louis, USA) solution $(0.5 \mathrm{mg}$ of MTT/mL of Phenol red-free cell culture medium). Cells were further incubated for $4 \mathrm{~h}$, and then the supernatants were decanted. A $0.08 \mathrm{M} \mathrm{HCl}$ solution in anhyd 2-propanol was added to each well in an amount equal to the original culture volume for dissolving the resulting MTT formazan crystals. The optical density of the converted dye was measured at $570 \mathrm{~nm}$ in a Multiskan Plate Reader (Multiskan EX, Labsystem, Finland).

2.2.5. Macrophage cell cultures. Cell cultures of bonemarrow-derived monocyte/macrophage cells were suspended in Dulbeco's modified Eagle's medium (DMEM) containing $10 \%$ of L929 cell-conditioned medium (LCCM also in DMEM), in 24-well tissue culture plates $\left(0.5 \times 10^{6}\right.$ cells/well $)$. The cells were incubated for 10 days at $37^{\circ} \mathrm{C}$, in a $93 \%$ humidified atmosphere with $7 \% \mathrm{CO}_{2}$. On day 4 , an additional volume of $100 \mu \mathrm{L}$ of LCCM was added, and on day 7 the medium was removed and replaced again by fresh DMEM with $10 \%$ of LCCM. After the 10th day of culture, when macrophage cells were fully differentiated, crude extract was added to the cell cultures at a final concentration of 25,250 or $2500 \mu \mathrm{g} / \mathrm{mL}$. Cultures stimulated with medium, $5 \mu \mathrm{g} /$ $\mathrm{mL}$ of LPS from Salmonella abortus equi (Sigma, St Louis) or the different polysaccharide fractions were incubated for 2, 6 and $24 \mathrm{~h}$. After those incubation periods cell-culture supernatants were collected for quantification of TNF or IL-10.

2.2.6. Macrophage cell-culture supernatants TNF and IL10 quantification. IL-10 concentrations from macrophage cell-culture supernatants were determined with the Quantikine ${ }^{\circledR}$ M mouse IL-10 immunoassay kit (R \& D systems, Minneapolis, MN, USA), by following the manufacturer's instructions. TNF quantification was done by an ELISA capture assay. ELISA plates (Maxisorp, Nunc, Roskilde, Denmark) were coated by overnight incubation with $100 \mu \mathrm{L} /$ well of anti-mouse TNF- $\alpha$ antibody (R \&D systems, Germany), at a concentration of $0.8 \mu \mathrm{g} / \mathrm{mL}$. The wells were then saturated for $1 \mathrm{~h}$ at room temperature with 1\% BSA in PBS. Undiluted cell culture supernatants and standard samples were then plated and incubated for $2 \mathrm{~h}$ at room temperature. After washing, the bound TNF was detected by addition of $100 \mu \mathrm{L} /$ well of biotinilated anti-TNF polyclonal antibody ( $\mathrm{R} \& \mathrm{D}$ systems) at a $300 \mathrm{ng} / \mathrm{mL}$ concentration and incubated for $2 \mathrm{~h}$ at room temperature. Washed plates were further incubated for $20 \mathrm{~min}$ with $100 \mu \mathrm{L} /$ well of peroxidase-coupled streptavidin. Substrate solution containing tetramethylbenzidine and $\mathrm{H}_{2} \mathrm{O}_{2}$ ( $\mathrm{R} \& \mathrm{D}$ systems) was added to each well after washing, and after a 20-min incubation the reaction 
was stopped adding $50 \mu \mathrm{L}$ of a solution containing $1 \mathrm{M}$ $\mathrm{H}_{2} \mathrm{SO}_{4}$. Optical density readings were made at $450 \mathrm{~nm}$ in a Biotek Chromoscan ELISA plate reader.

2.2.7. Flow cytometry analysis. For cytometry analysis, $\mathrm{C} 57 \mathrm{Bl} / 6$ or $\mathrm{C} 57 \mathrm{BL} / 10 \mathrm{ScCr}$ mice spleen cells were resuspended in balanced salt solution (BSS) supplemented with $10 \mathrm{mM}$ of sodium azide and $1 \%$ bovine serum albumin (BSA). The following monoclonal antibodies were used for immunofluorescence cytometric analysis in a FACScan (Becton Dickinson, San Jose, CA, USA): goat anti-mouse IgM FITC conjugate (Southern Biotechnology Associates, Birmingham, ALA, USA), hamster anti-mouse CD3 FITC conjugate (Southern Biotechnology Associates, Birmingham, ALA, USA), hamster antimouse CD69 (PharMingen, San Diego, CA, USA) PE conjugate or biotinilated rat anti-mouse CD25 (Southern Biotechnology Associates Birmingham, ALA, USA). CELlquest software (Becton Dickinson) was used to process the gathered data. Biotinilated antimouse CD25 antibody was detected with PE-conjugated avidin (Southern Biotechnology Associates Birmingham, ALA, USA). Dead cells were excluded by propidium iodide incorporation.

\section{Results and discussion}

\subsection{Carbohydrate analysis}

In the present work we characterised some structural features of a CWM extract obtained with $4 \mathrm{M}$ $\mathrm{KOH}+\mathrm{H}_{3} \mathrm{BO}_{3}$. The main sugars of this crude extract (Table 1) are Ara (52 $\mathrm{mol} \%)$, HexA (25 mol\%) and Xyl (14 mol\%).

A viscous solution was obtained when the crude extract was dispersed in distilled water, in concentrations above $10 \mathrm{mg} / \mathrm{mL}$. This prevented fractionation of the polysaccharides by graded ethanol precipitation (data not shown). Despite of the observed viscous character, rheological experiments (with concentrations ranging from 10 to $30 \mathrm{mg} / \mathrm{mL}$, in water) showed that this solution does not display the characteristic behaviour of a true gel (data not shown).

Anion-exchange chromatography experiments were done by dispersing the crude extract in $50 \mathrm{mM}$ Tris$\mathrm{HCl}$ at a $\mathrm{pH}$ of 5.5 and 7.0 , and in $0.1 \mathrm{M} \mathrm{NaOH}$, to a final concentration of $1 \mathrm{mg} / \mathrm{mL}$. At this concentration, the solutions were not viscous. Each sample was then fractionated on a DEAE Sepharose Fast Flow column. For the $0.1 \mathrm{M} \mathrm{NaOH}$ dispersed sample (Fig. 1), two neutral $(\mathrm{A}$ and $\mathrm{B})$ and three acidic fractions $(\mathrm{C}, \mathrm{D}$ and $\mathrm{E}$; Table 1) were obtained. The recovery of the eluted material was almost quantitative $(92 \%)$. The essentially noncarbohydrate material $(10 \%$ of the crude extract) was resolved in fractions $\mathrm{B}, \mathrm{C}$ and $\mathrm{D}$. Fractions $\mathrm{A}$ and $\mathrm{E}$ are very rich in sugars, the acidic fraction $\mathrm{E}$ representing ca. $70 \%$ of the crude extract. These fractions have a similar sugar composition (and also similar to the crude extract), but fraction $\mathrm{E}$ could be eluted only with more than $0.5 \mathrm{M} \mathrm{NaCl}$ (Fig. 1). The crude extract was obtained from $P$. dulcis $\mathrm{CWM}$ with a $4 \mathrm{M} \mathrm{KOH}+\mathrm{H}_{3} \mathrm{BO}_{3}$ treatment. Since alkaline solvents cause de-esterification of the polysaccharide's acidic groups, it is unlikely that the acidic residues from fraction $\mathrm{A}$ are esterified. As these polysaccharides contain ca. 25\% HexA (Table 1), they should be negatively charged. However, they do not interact with the DEAE matrix. In addition, comparing the elution profiles obtained using Tris- $\mathrm{HCl}$ (pH 5.5) buffer and $\mathrm{NaOH}$ solutions as eluents, it was observed that, by increasing the $\mathrm{pH}$, the recovery of the acidic fractions increased by approximately five-fold (data not shown). These observations suggest that, even at high $\mathrm{pH}$ values, macromolecular aggregates

Table 1. Monosaccharide composition of the crude extract and fractions obtained by anion-exchange chromatography on DEAE Sepharose Fast Flow $^{\mathrm{a}}$

\begin{tabular}{|c|c|c|c|c|c|c|c|c|c|c|}
\hline \multirow[t]{2}{*}{ Fraction } & \multirow[t]{2}{*}{ Recovery $(\% \mathrm{w} / \mathrm{w})$} & \multicolumn{8}{|c|}{ Cell-wall sugars $(\mathrm{mol} \%)$} & \multirow[t]{2}{*}{ Total sugars $^{\mathrm{c}}\left(\mathrm{mgg}^{-1}\right)$} \\
\hline & & Rha & Fuc & Ara & Xyl & Man & Gal & Glc & HexA & \\
\hline Crude & & 3 & $\operatorname{Tr}^{\mathrm{b}}$ & 52 & 14 & $\operatorname{Tr}$ & 5 & $\operatorname{Tr}$ & 25 & 842 \\
\hline \multicolumn{11}{|c|}{ Neutral anion exchange } \\
\hline A & $10.6^{\mathrm{d}}$ & 2 & $\operatorname{Tr}$ & 59 & 10 & $\operatorname{Tr}$ & 3 & $\operatorname{Tr}$ & 24 & 988 \\
\hline $\mathrm{B}$ & 3.6 & 2 & 3 & 64 & 11 & 1 & 3 & 1 & 13 & 292 \\
\hline \multicolumn{11}{|c|}{ Acidic anion exchange } \\
\hline $\mathrm{C}$ & 1.8 & 4 & 37 & 21 & 9 & 16 & & 14 & & 30 \\
\hline $\mathrm{D}$ & 4.3 & 2 & 8 & 40 & 14 & $\operatorname{Tr}$ & 3 & 2 & 30 & 220 \\
\hline $\mathrm{E}$ & 71.4 & 3 & $\operatorname{Tr}$ & 53 & 11 & $\operatorname{Tr}$ & 4 & $\operatorname{Tr}$ & 28 & 995 \\
\hline
\end{tabular}

${ }^{a}$ Neutral fractions where eluted with $0.1 \mathrm{M} \mathrm{NaOH}$, and the acidic fractions were eluted with a linear gradient of $\mathrm{NaCl}(0-1 \mathrm{M}$ in the same alkaline solution).

${ }^{\mathrm{b}} \mathrm{Tr}=$ traces; HexA = hexuronic acid; blank spaces = not detected.

${ }^{\mathrm{c}}$ Values are expressed as milligram anhydrosugar per gram.

${ }^{\mathrm{d}}$ Value is expressed as \%-crude extract. 
are present in the aqueous crude extract solutions, being eluted in the neutral fraction. The interaction between the acidic groups of the polysaccharide and the charged groups of the resin may, therefore, be restricted by steric hindrance effects due to aggregation. In alkaline media, these aggregates represent ca. $10 \%$ (Table 1, fraction A) of the mass of the crude extract.

The average molecular masses $\left(M_{\mathrm{r}}\right)$ and the size distribution profiles of the crude extract and of fractions A and $\mathrm{E}$ were determined by size-exclusion chromatography (Fig. 2). Unlike proteins, monodisperse polysaccharides are rarely, if ever, found. Generally, polysaccharides show chemical or physical heterogeneity. If the polymer is chemically homogeneous (composed of identical repeating units) but physically heterogeneous (whose molecular weight vary), it is termed as polymolecular. ${ }^{38}$ This seems to be the case of fractions A and E (Fig. 2): fractions collected at different stages of the elution and analysed for sugar composition revealed that the chemical composition of the eluted polysaccharide is similar (data not shown). This observation strongly suggests that the polysaccharide is homogeneous. From the elution profile of the crude extract (Fig. 2), it seems to be a composition of fractions $\mathrm{A}$ and $\mathrm{E}$, since two peaks were observed along the curve (as an estimate, fraction A accounts for ca. 15\% and fraction E, $85 \%$ of the total area of the curve). Fraction A has a narrower $M_{\mathrm{r}}$ distribution profile than fraction E. Using dextrans as standards, the $M_{\mathrm{r}}$ values were calculated to be $1.76 \mathrm{MDa}$ and $762 \mathrm{kDa}$ for fractions A and E, respectively. Similar values were obtained by lightscattering experiments. Pectins' $M_{\mathrm{r}}$ ranges from 30 to

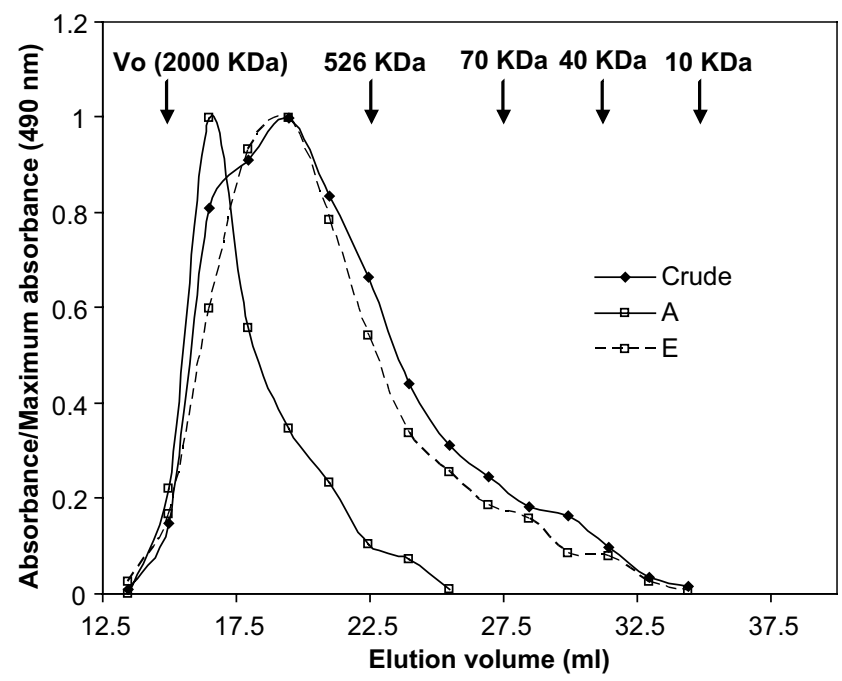

Figure 2. Elution profile of the crude extract and fractions $\mathrm{A}$ and $\mathrm{E}$ on a Sephacryl S-400 HR column. The crude extract, fractions A and E $(1 \mathrm{mg} / \mathrm{mL})$ were injected $(500 \mu \mathrm{L})$ into the column, and $0.1 \mathrm{M} \mathrm{NaOH}$ was used as the eluent. Fractions were collected and monitored by the phenol- $\mathrm{H}_{2} \mathrm{SO}_{4}$ method. $V_{\mathrm{o}}$-void volume.
$300 \mathrm{kDa} .{ }^{39}$ However, higher molecular mass polysaccharides have also been reported. ${ }^{40}$

The crude and fractions $\mathrm{A}$ and $\mathrm{E}$ were dispersed and eluted in water and $0.1 \mathrm{M} \mathrm{NaOH}$. Size-exclusion chromatography showed that, at a higher $\mathrm{pH}$, a broadening of the crude extract elution profile into the regions of smaller molecular masses occurs. However, no significant changes were detected in either the elution profiles, or the estimated $M_{\mathrm{r}}$ of fractions A and E. This was also confirmed by light scattering. The aggregation by polysaccharides such as pectins and arabinogalactans, even when dissolved in $0.2 \mathrm{M} \mathrm{NaCl}$, has been described previously. ${ }^{41,42}$ These results suggest that further dispersion of the aggregates from fraction $\mathrm{A}$ is not possible under the experimental conditions used.

To identify the main type of glycoside linkages present, the crude extract and fractions A and E were subjected to methylation analysis (Table 2). Since the total amount of terminal residues is coherent with the total amount of branching points, all polysaccharides appear to have been completely methylated.

FTIR analysis of the crude fraction showed that the uronic acid content is from GalA only. ${ }^{29}$ As inferred from the various linked GalA, Rha, Gal and a significant proportion of the Ara residues, the polysaccharide in study is possibly an arabinan-rich pectic polysaccharide. Ara represents $70-80 \%$ of the structural unit of the polysaccharides, as calculated from the total amount of Ara derivates (Table 2). However, according to Table 1, Ara accounts only for $40-50 \%$ of the total sugar content. As the overall recoveries of GalA were very low $(9-20 \%)$, that difference is due to this poor recovery. For low \%-sugar (such as the case with Rha and Gal; Table 1), the variation in the total \%-values is not significant.

The predominant peaks of the methylated products were assigned to $t$-Araf: $(1 \rightarrow 5)>\operatorname{Araf}:(1 \rightarrow 3,5)>$ Araf:$(1 \rightarrow 2,3,5)>$ Araf. The high proportion of terminal residues, $90-95 \%$ of which are Ara, suggests a very low mean degree of polymerisation (DP2, as estimated by the ratio of total Ara residues to terminally linked Ara residues). In addition to the high amounts of Ara (Table 1), the proportions of the main residues $(30 \%$ of the total Ara correspond to branching points though O-3 and through $\mathrm{O}-2$ and $\mathrm{O}-3$; Table 2) suggests that the crude extract and its fractions are composed by highly branched arabinan side chains. In all cases, the polysaccharides possess structural Ara moieties with highly branched arabinan-rich pectic polysaccharides containing a 5)-Araf- $(1 \rightarrow$ backbone. The average relative proportions of the arabinosyl linkages was 3:2:1:1 for $t$-Ara $f:(1 \rightarrow 5)$-Araf:(1 $\rightarrow 3,5)$-Ara $f:(1 \rightarrow 2,3,5)$-Ara $f$, comparable to the arabinan from cabbage. ${ }^{43}$

According to the linkage composition of the xylosil residues, a highly branched xylan-type polysaccharide may be present. As inferred from the average ratio of 
Table 2. Partially methylated alditol acetates of the crude polysaccharide extract and fractions A and E, from $P$. dulcis seeds

\begin{tabular}{|c|c|c|c|c|c|}
\hline \multirow[t]{2}{*}{ Sugar } & \multirow[t]{2}{*}{ Deduced linkage } & \multirow[t]{2}{*}{ Sugar derivate } & \multicolumn{3}{|c|}{$\mathrm{mol}(\%)$} \\
\hline & & & Crude & $\mathrm{A}$ & $\mathrm{E}$ \\
\hline \multicolumn{6}{|l|}{ Rha } \\
\hline & 2,4)-Rhap-(1 $\rightarrow$ & 3-Me rhamnitol & 1.8 & 1.4 & 3.3 \\
\hline & $2,3,4)-$ Rhap- $(1 \rightarrow$ & Rhamnitol & 0.3 & 0.3 & 0.4 \\
\hline \multicolumn{6}{|l|}{ Ara } \\
\hline & $\operatorname{Ara} f-(1 \rightarrow$ & 2,3,5- $\mathrm{Me}_{3}$ arabinitol & 38.6 & 36.3 & 30.5 \\
\hline & $5)-\operatorname{Ara} f-(1 \rightarrow$ & 2,3- $-\mathrm{Me}_{2}$ arabinitol & 19.5 & 19.4 & 16.8 \\
\hline & $3)-\operatorname{Ara} f-(1 \rightarrow$ & $2,5-\mathrm{Me}_{2}$ arabinitol & 0.6 & 0.5 & 1.3 \\
\hline & $3,5)-\operatorname{Ara} f-(1 \rightarrow$ & 2-Me arabinitol & 13.3 & 12.9 & 11.4 \\
\hline & $2,3,5)-\operatorname{Ara} f-(1 \rightarrow$ & Arabinitol & 10.7 & 13.3 & 8.8 \\
\hline \multicolumn{6}{|l|}{ Xyl } \\
\hline & $\mathrm{Xyl} p-(1 \rightarrow$ & 2,3,4- $\mathrm{Me}_{2}$ xylitol & 0.8 & 1.1 & 0.7 \\
\hline & 4)-Xylp-(1 $\rightarrow$ & 2,3-Me $\mathrm{Me}_{2}$ ylitol & 1.5 & 3.2 & 2.8 \\
\hline & $2,4)-\mathrm{Xyl} p-(1 \rightarrow$ & 3-Me xylitol & 4.7 & 5.5 & 4.2 \\
\hline \multicolumn{6}{|l|}{ Gal } \\
\hline & Galp- $(1 \rightarrow$ & $2,3,4,6-\mathrm{Me}_{4}$ galactitol & 1.3 & 0.9 & 2.1 \\
\hline & 3)-Galp-(1 $\rightarrow$ & $2,4,6-\mathrm{Me}_{3}$ galactitol & 1.4 & 1.5 & 2.0 \\
\hline & $3,4)-\mathrm{Gal} p-(1 \rightarrow$ & $2,6-\mathrm{Me}_{2}$ galactitol & & & 0.6 \\
\hline & 4)-Galp-(1 $\rightarrow$ & $2,3,6-\mathrm{Me}_{3}$ galactitol & 2.9 & 2.2 & 8.5 \\
\hline & $3,6)-\mathrm{Gal} p-(1 \rightarrow$ & $2,4-\mathrm{Me}_{2}$ galactitol & 0.4 & 0.3 & 0.4 \\
\hline & $2,4)-\mathrm{Gal} p-(1 \rightarrow$ & $3,6-\mathrm{Me}_{2}$ galactitol & 0.3 & 0.3 & 0.5 \\
\hline \multicolumn{6}{|l|}{ GalA } \\
\hline & 4)-GalpA-(1 $\rightarrow$ & 2,3- $\mathrm{Me}_{2}$ galactitol $(d)$ & 1.7 & 1.0 & 4.8 \\
\hline & GalA- $(1 \rightarrow$ & $2,3,4-\mathrm{Me}_{3}$ galactitol $(d)$ & 0.4 & & 0.7 \\
\hline
\end{tabular}

Blank spaces $=$ not detected, $(d)=$ deuterated in C-6.

the total Xyl residues to terminally linked ones, the mean degree of polymerisation is about 10 .

As this extract was obtained following several alkaline extractions, these xylan chains must be closely associated to the pectic polysaccharides, possibly as side chains of a rhamnogalacturonan type I main chain. A pectic polysaccharide with similar characteristics (both structural and immunoactive) was described by Duan et $a .^{40}$ In this case, xylose is present in the side chains of the pectin as an arabinoxylan. The presence of xylose in the pectic polysaccharides was also referred by other authors. ${ }^{44}$

\subsection{Immunomodulatory activity assays}

In order to investigate a putative immunomodulatory effect of the polysaccharides, the crude extract was tested for the induction of activation on murine lymphocyte cells. Contaminant endotoxins were removed from the polysaccharide preparations by affinity chromatography in a polymyxin B coupled column. The culture medium was also supplemented with this antibiotic, as previously described. ${ }^{45,46}$ As shown in Figure 3, an increased expression of the early activation marker CD69 was observed on the surface of B-cells after $6 \mathrm{~h}$ in vitro stimulation of C57BL/6 mice spleen mononuclear cell cultures with $250 \mu \mathrm{g} / \mathrm{mL}$ of the crude extract. This in vitro B-cell stimulatory effect was also observed in mononuclear spleen-cell cultures of the bacterial lipopolysaccharide (LPS)-tolerant C57BL/10 ScCr strain of mice (Qureshi ST) (Fig. 3). These results indicate that the crude extract's B-cell stimulatory effect is not due to contaminant endotoxin. Moreover, since C57BL/10 $\mathrm{ScCr}$ mice did not express toll-like receptor 4 (Qureshi $\mathrm{ST}$ ), the B lymphocyte activatory signal is thus independent of this cell-surface receptor. A small fraction of T-cells were also induced to express CD69, as observed $6 \mathrm{~h}$ after the polysaccharide treatments of the spleen mononuclear cells cultures of both C57BL/6 and C57BL/10 mice strains (Fig. 3).

In line with the observed increase of CD69 expression, C57BL/6 mice spleen mononuclear cells cultured for three days in the presence of $250 \mu \mathrm{g} / \mathrm{mL}$ of the crude extract exhibited a mild proliferative response (Fig. 4A). This proliferative effect was not detected when 2- to 10-fold lower doses of crude extract were used to stimulate the cell cultures (data not shown). This stimulatory effect of the crude extract on murine spleen lymphocytes was also indicated by the increased surface expression of CD25 (a lymphocyte activation marker expressed later than CD69) observed on $\mathrm{B}$-cells $(\operatorname{IgM}+)$, in these mononuclear cell cultures (Fig. 4B).

Interestingly, the in vitro stimulation of cultures of pure macrophage cells with the crude extract did not induce the production of either TNF or IL-10, two 
C57BL/6

CD69

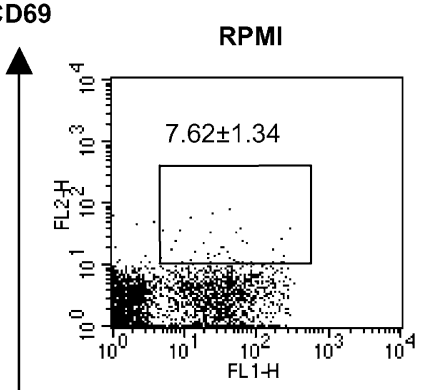

$\lg M$

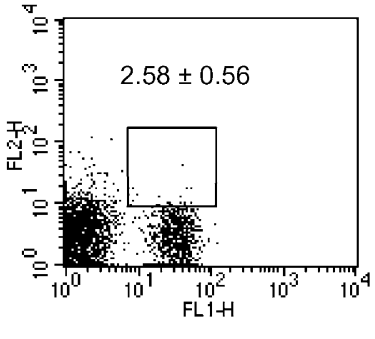

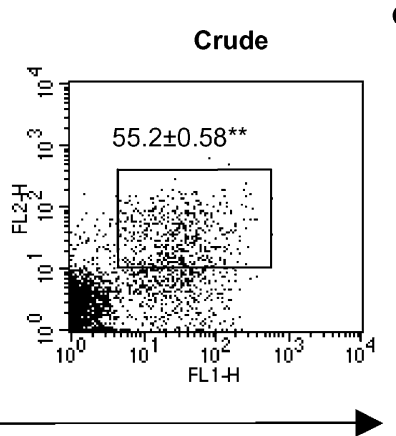

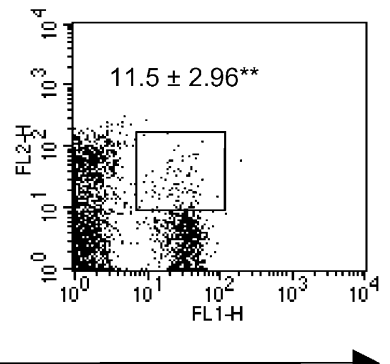

CD3
$\mathrm{C} 57 \mathrm{BL} / 10 \mathrm{ScCr}$

CD69
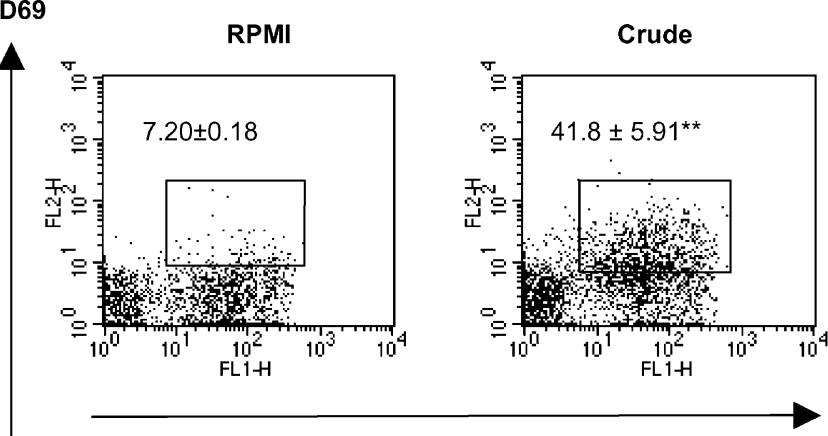

$\lg M$
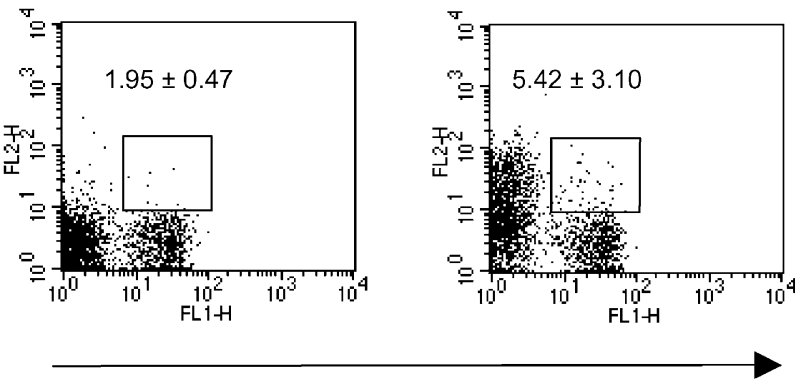

CD3

Figure 3. In vitro lymphocyte stimulatory effect of crude extract. Flow cytometric analysis of CD69 expression on the surface of C57/BL6 or C57BL/ $10 \mathrm{ScCr}$ mice $\mathrm{B}\left(\mathrm{IgM}^{+}\right)$and $\mathrm{T}\left(\mathrm{CD}^{+}\right)$cells in spleen mononuclear cell cultures after $6 \mathrm{~h}$ incubation with $250 \mu \mathrm{g} / \mathrm{mL}$ of crude extract (crude) or medium alone (RPMI). Numbers represent the percentage of CD69-expressing cells on the indicated lymphocyte populations and are the means plus one SD of three samples per group of a representative experiment repeated four times. In this and in following Figures 4, 6 and 7 statistically significant differences between control and crude extract-treated groups $\left(* * p<0.01\right.$ or $\left.{ }^{*} p<0.05\right)$ are indicated.

cytokines produced by stimulated macrophages, ${ }^{47,48}$ even when a high dose $(2500 \mu \mathrm{g} / \mathrm{mL})$ of crude extract was used (Fig. 5). Stimulation with 25 or $250 \mu \mathrm{g} / \mathrm{mL}$ of crude extract also did not induce the production of these two cytokines (data not shown). This lack of TNF production is in accordance with the lack of detectable cytotoxicity, observed in mononuclear cell cultures stimulated with the crude extract within the range of concentrations used in these experiments. Also, lack of TNF induction further excludes the presence of contaminating endotoxin on the polysaccharide samples.

A lymphocyte stimulatory effect, as measured by the induction of CD69 expression, was also observed in vitro and in vivo with fractions $\mathrm{A}$ and $\mathrm{E}$. Thus, an increase in CD69 expression was observed on the surface of B-cells and to a lesser extent on T-cells, $6 \mathrm{~h}$ after in vitro treatment of C57BL/6 spleen mononuclear cells cultures with $125 \mathrm{~g} / \mathrm{mL}$ of fractions A or E (Fig. 6). As also shown in Figure 6, fraction $\mathrm{E}$ was a more potent B-cell stimulator than fraction A.

The lymphocyte stimulatory capacity of fraction E, as well as that of the crude extract, was also studied in vivo, and an increased CD69 expression was observed in the surface of splenic B-cells $6 \mathrm{~h}$ after i.p. treatment of
C57BL/ 6 mice with $250 \mu \mathrm{g}$ of fraction $\mathrm{E}$ or crude extract, as compared to PBS-inoculated controls. The in vivo Bcell stimulatory effect was more pronounced in fraction E than in crude extract-treated mice (Fig 7). In contrast with the in vitro treatments, the expression of CD69 on the surface of T-cells was not increased in the crude extract-treated mice with the dose used, but was detected in fraction E-treated mice as also shown in Figure 7.

Several other polysaccharides have previously been shown to induce the activation of B-cells and/or T-cells, namely, a pectic polysaccharide from the roots of the medicinal herb Bupleurum falcatum L., ${ }^{27}$ an inulin-type polysaccharide isolated from the radix of Platycodon grandiflorum or Angelan, a pectic polysaccharide isolated from $A$. gigas Nakai that was reported to directly activate macrophages and B-cells, but not T-cells. ${ }^{49-51}$

Putative immunomodulatory applications of the polysaccharide fractions studied here will need further investigation. An adjuvant effect on immunisation against proteinaceous antigens could be a possibility. Alternatively, since increased susceptibility to infections or autoimmune pathology often arise as a consequence of 

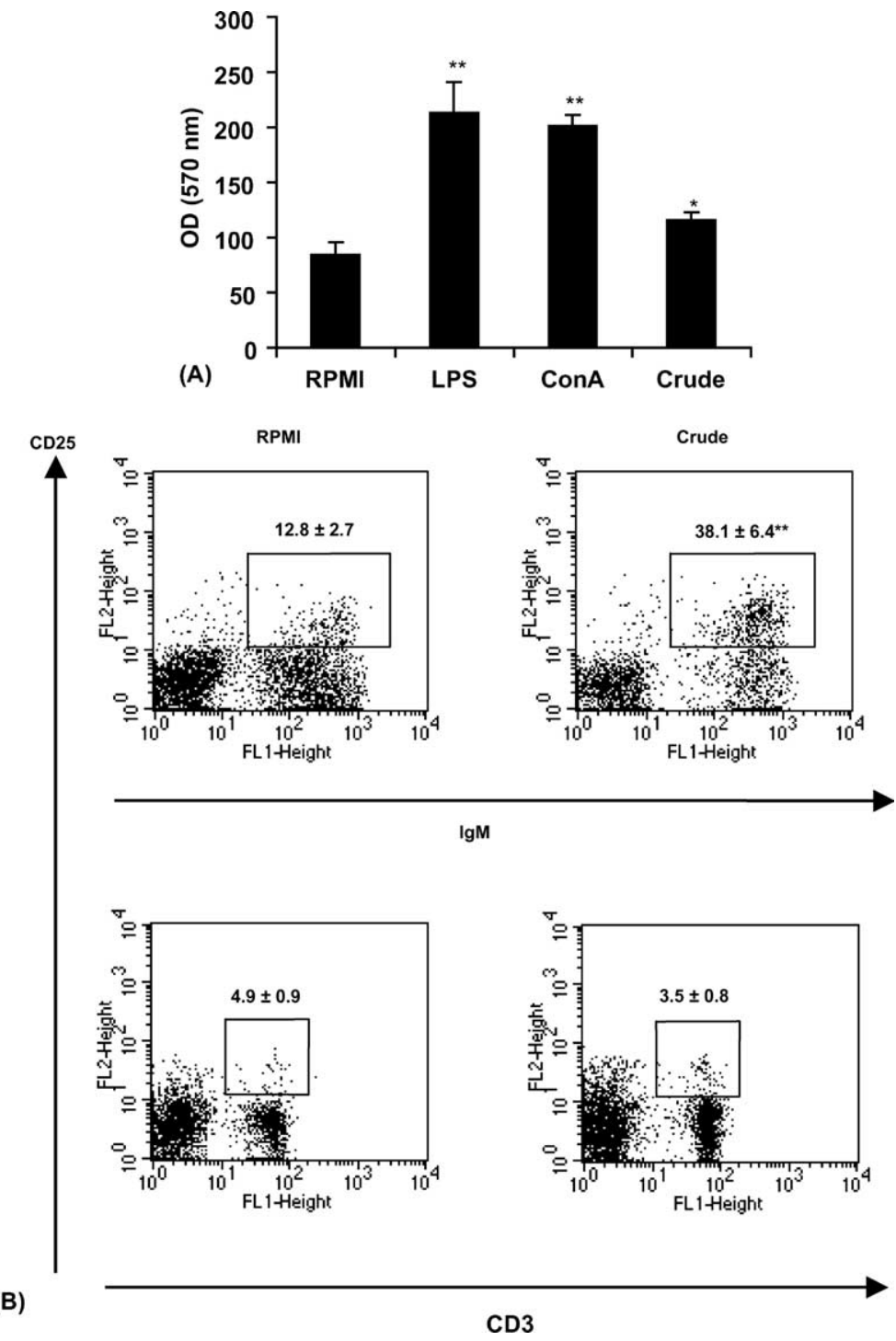

Figure 4. Lymphocyte stimulatory effect of crude extract on three-days spleen mononuclear cell cultures. (A) Proliferative index evaluated with the MTT proliferation assay of C57BL/6 spleen mononuclear cells cultures stimulated with medium alone (RPMI), LPS $(5 \mu \mathrm{g} / \mathrm{mL})$, Concanavalin A $(5 \mu \mathrm{g} / \mathrm{mL})$ or crude extract $(250 \mu \mathrm{g} / \mathrm{mL})$. (B) Flow cytometric analysis of CD25 expression on the surface of C57/BL6 B $\left(\operatorname{IgM}^{+}\right)$and T $\left(C D 3^{+}\right)$cells in spleen mononuclear cell cultures after incubation for 3 days with $250 \mu \mathrm{g} / \mathrm{mL}$ of crude extract (crude) or medium alone (RPMI). Numbers represent the percentage of $\mathrm{CD} 25$-expressing cells on the indicated lymphocyte populations and are means plus one SD of three samples per group of a representative experiment repeated three times.

or associated with diverse primary or secondary B-cell immunodeficiencies, ${ }^{52,53}$ including those related to ageing ${ }^{54,55}$ it is tempting to hypothesise that due to their B-cell stimulatory effect, crude extract or fractions E or A could be of potential preventive or therapeutic application in these situations. A beneficial effect on immune-mediated response against Staphylococcus aureus and Eimeria vermiformis was previously reported for another polysaccharide of plant origin in a murine model. ${ }^{21}$ Interestingly, the polysaccharide used in the present report was unable to stimulate murine macrophages to produce the pro-inflammatory cytokine TNF. This could be of relevance regarding putative immunomodulatory applications of this product since the deleterious effects of an excessive production of TNF are well known as epitomised in septic shock. ${ }^{56}$ Also, although less marked than on B-cells, a stimulatory effect of the crude extract and fractions E and A was detected on a small fraction of T-cells. It will thus be of interest to characterize the surface and functional phenotype of these responding cells.

The search for novel compounds that show immunomodulatory activities - without severe side effects to the host-has become an important goal of research in the biomedical sciences. Several studies have been carried out with polysaccharides isolated from plant sources. 

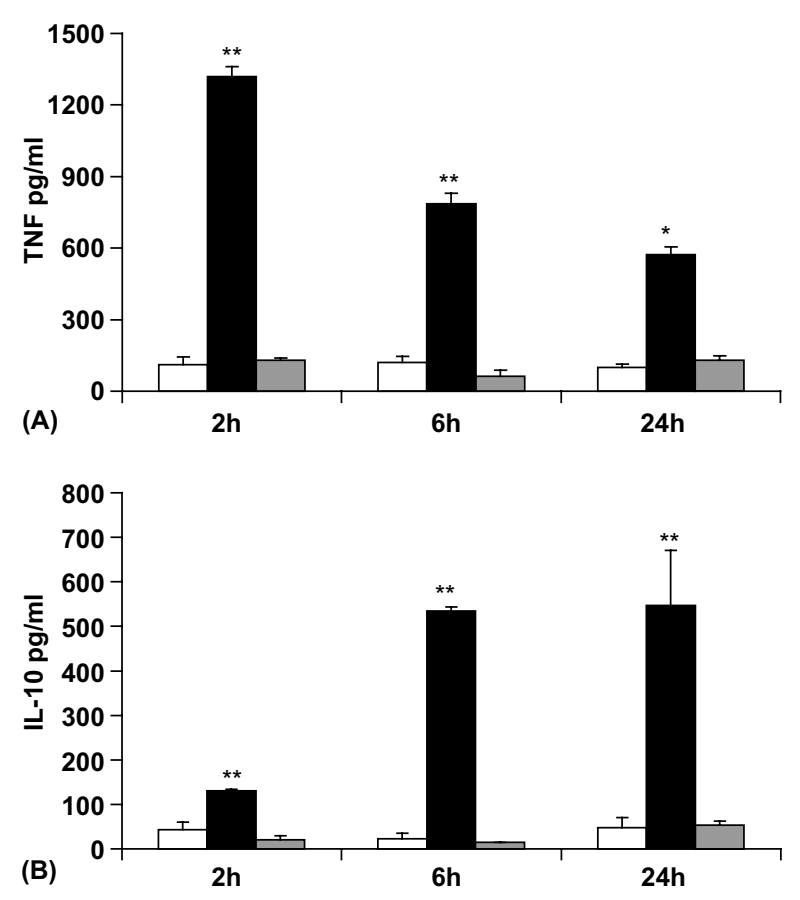

Figure 5. TNF and IL-10 production by macrophage cells stimulated with crude extract. TNF (A) and IL-10 (B) concentrations in culturesupernatants of pure macrophage cells. Cell-culture supernatants were harvested at the indicated time points after stimulation with medium alone (open bars), $5 \mu \mathrm{g} / \mathrm{mL}$ of LPS (closed bars) or with $2500 \mu \mathrm{g} / \mathrm{mL}$ of crude extract (shaded bar). Results are the means plus one SD of triplicate samples and representative of an experiment repeated twice.

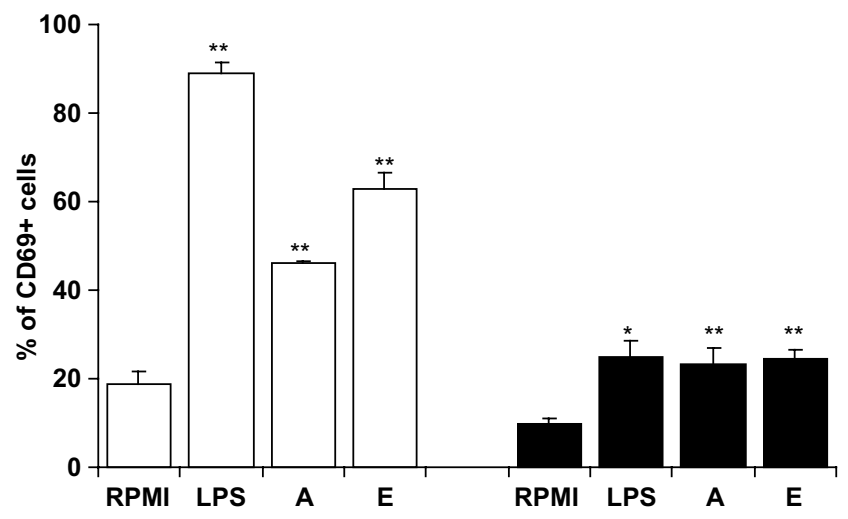

Figure 6. In vitro lymphocyte stimulatory effect of fraction A and E. Percentage of CD69-expressing $\mathrm{B}\left(\mathrm{IgM}^{+}\right)$-cells (open bars) or $\mathrm{T}$ $\left(\mathrm{CD}^{+}\right)$-cells (closed bars) cells in C57BL/6 mice spleen mononuclear cells cultures stimulated for $6 \mathrm{~h}$ with medium alone (RPMI), $5 \mu \mathrm{g} / \mathrm{mL}$ of LPS (LPS) or with $125 \mu \mathrm{g} / \mathrm{mL}$ of either fraction A (A) or fraction E (E). Numbers represent the percentage of CD69-expressing cells among the indicated lymphocyte populations and are means plus one SD of triplicate samples of a representative experiment repeated three times.

Different immunomodulating properties were reported. The potential usefulness of immunomodulating polysac- charides in the treatment of some diseases has been demonstrated in preclinical and clinical studies. While the activity of some of these polysaccharides has been known over the last decades, the lack of further purification and of comprehensive structural and mechanistic information has limited the effort to study their potential for clinical use.

Data gathered from the research presented herein, justifies the interest for future work that will include a more detailed structural characterization of the Ara-rich pectic polysaccharides from the CWM of $P$. dulcis. In addition, several bioactivities will be tested: anti-tumour, immunostimulating, anti-complementary, anti-inflammatory, reticuloendothelial system-potentiating, anticoagulant and fibrinogenic, to name a few. These studies will allow a better understanding of the mechanism and structural aspects of the polysaccharides that modulate the potential bioactivities.

The scientific literature shows that the tailoring of the polysaccharides with enzymes further enhances the bioactivity of the polysaccharides. Future work will also focus on the partial enzymatic degradation of the polysaccharides and assessment of influence of the enzymatic treatment on the bioactivities tested. This may also shed light on to the minimal structure of the polysaccharide responsible for a given bioactivity.

The possibility of using polysaccharides alone or in conjunction with other already existing chemical alternatives would be of great interest in therapeutic applications and will also be investigated.

\section{Conclusions}

An arabinan-rich pectic polysaccharide, with an apparent molecular mass $762 \mathrm{kDa}$ was isolated from $P$. dulcis seed cell walls. The highly branched arabinan moiety contains a $(1 \rightarrow 5)$-Araf backbone. The average relative proportions of the arabinosyl linkages was 3:2:1:1

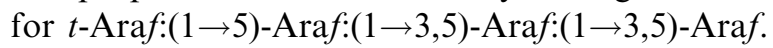

Immunomodulatory activity assays showed that the crude extract stimulate the surface expression of the lymphocyte activation markers CD69 and CD25 on the surface of B-cells and of CD69 in the surface of Tcells, and also mononuclear cell-culture proliferation. The lymphocyte stimulatory effect as evaluated by CD69 expression was also obtained with the acidic fraction (E) and with the neutral fraction (A). In the range of concentrations used in these experiments, no evidence of cytotoxic effects induced by the polysaccharide fractions was found.

Further research on the structure and relationship between structure and the immunobiologic activities of the purified polysaccharides from $P$. dulcis seed is required and is currently in progress. 


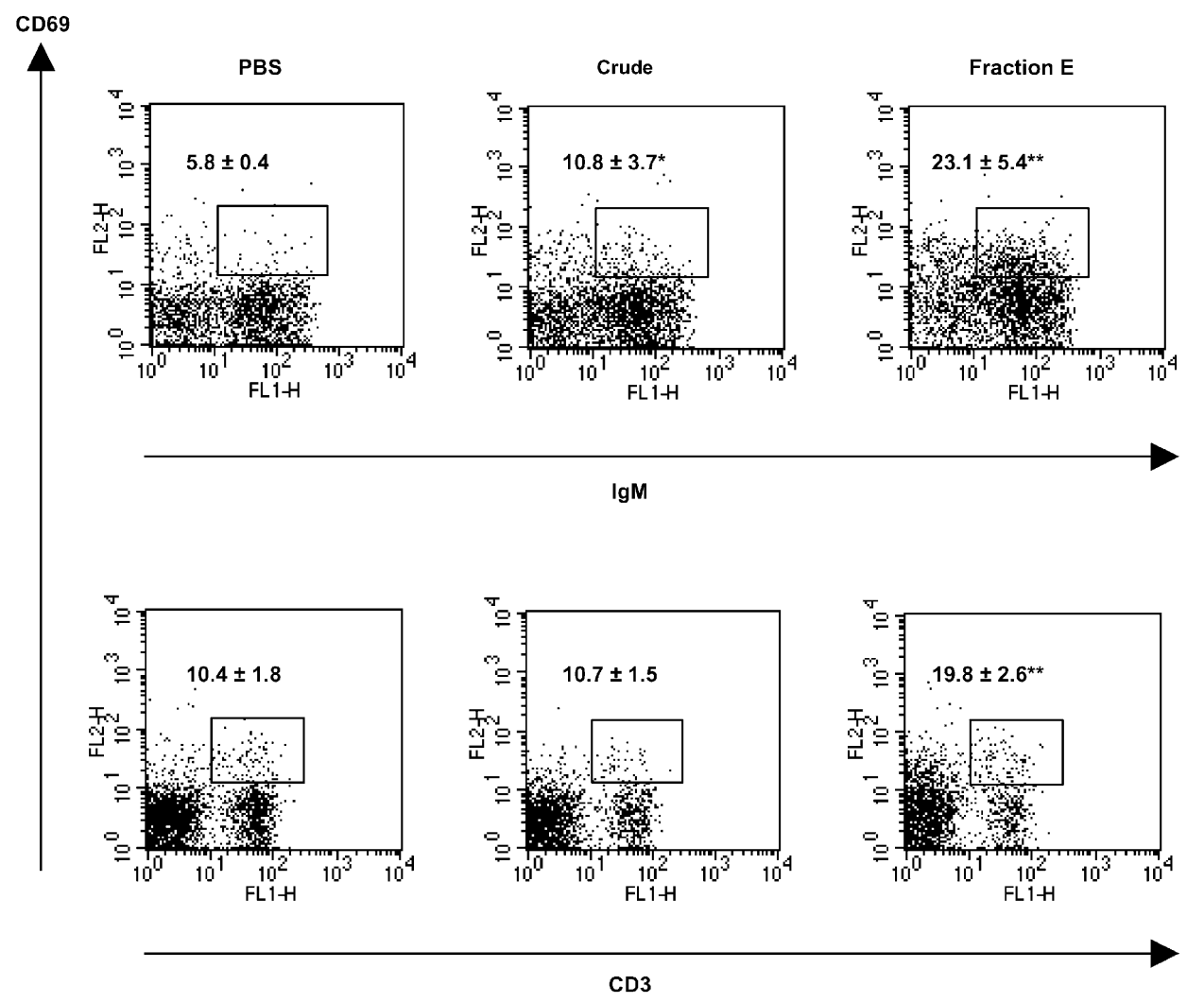

Figure 7. In vivo lymphocyte stimulatory effect of fraction $\mathrm{E}$ or crude extract. Flow cytometric analysis of CD69 expression on the surface of spleen $\mathrm{B}\left(\mathrm{IgM}^{+}\right)$and $\mathrm{T}\left(\mathrm{CD}^{+}\right)$cells of C57/BL6 mice $6 \mathrm{~h}$ after inoculation i.p. with $0.25 \mathrm{~mL}$ of PBS or $0.25 \mathrm{~mL}$ of PBS containing $250 \mu \mathrm{g}$ of crude extract or fraction $\mathrm{E}$ as indicated. Numbers represent the percentage of CD69-expressing cells among the indicated lymphocyte populations. These are means plus one SD of four mice per group and are a representative experiment repeated twice.

\section{Acknowledgements}

F. Dourado thanks FCT (Portugal) for the Doctoral grant No PRAXIX XXI/BD/18401/98. The authors acknowledge Pedro Vasco (University of Aveiro) for help with the methylation and carboxyl reduction of the polysaccharide samples and GC-MS analyses.

\section{References}

1. Roitt, I.; Broshtoff, J.; Male, D. Immunology, 5th ed.; Mosby International Ltd: London, 1998.

2. Goldsby, R. A.; Kindt, T. J.; Osborne, B. A. Immuno$\log y$, 4th ed.; W. H. Freeman and Company: New York, 2000 .

3. Cohn, M. Immunol. Rev. 2002, 185, 24-38.

4. Tzianabos, A. O. Clin. Microb. Rev. 2000(October), 523533.

5. Stimpel, M.; Proksch, A.; Wagner, H.; Lohman-Mathes, M.-L. Infect. Immun. 1984(December), 845-849.

6. Shimizu, N.; Asahara, H.; Tomoda, M.; Gonda, R.; Ohara, N. Chem. Pharm. Bull. 1991, 39, 2630 2632.

7. Gonda, R.; Takeda, K.; Shimizu, N.; Tomoda, M. Pharm. Bull. 1992, 40, 185-188.

8. Benencia, F.; Rodriguez, M. C.; Matulewicz, M. C.; Colombié, F. C. Phytochemistry 1999, 50, 57-62.
9. Silva, B. P.; Tostes, J. B. F.; Parente, J. P. Fitoterapia 2000, 71, 516-521.

10. Yamada, H.; Kiyohara, H.; Cyong, J.-C.; Otsuka, Y. Mol. Immunol. 1985, 22, 295-304.

11. Yamada, H. Carbohydr. Polym. 1994, 25, 26-275.

12. Chung, H.; Shin, D. H.; Hong, B. S.; Cho, W. D.; Cho, H. Y.; Yang, H. C. Biol. Pharm. Bull. 2002, 25, 12031208.

13. Fujiwara, T.; Sugishita, E.; Takeda, T.; Ogihara, Y.; Shimizu, M.; Nomura, T.; Tomita, T. Chem. Pharm. Bull. 1984, 32, 1385-1391.

14. Hussein, M. M.-D.; Helmy, W. A.; Salem, H. M. Phytochemistry 1998, 48, 479-484.

15. Young, C. K.; Cunningham, S. Cereal Food World 1991, 36, 412-418.

16. Saura-Calixto, F.; Bauza, M.; Martinez de Toda, F.; Argamenteria, A. J. Agric. Food Chem. 1981, 29, 509-511.

17. Esteban, R. M.; López-Andréu, F. J.; Carpena, O. J. Sci. Food Agric. 1985, 36, 485-490.

18. Hotellier, M. F.; Delaveau, P. Ann. Pharm. Franç. 1972, $78,495-502$.

19. Nassar, A. R.; El-Tahawi, B. S.; El-Deen, S. A. S. J. Am. Oil Chem. Soc. 1977, 54, 553-556.

20. Currier, N. L.; Lejtenyi, D.; Miller, S. C. Phytomedicine 2003, 10, 145-153.

21. Yun, C. H.; Estrada, A.; Van Kessel, A.; Park, B. C.; Laarveld, B. FEMS Immunol. Med. Microbiol. 2003, 35, $67-75$.

22. Bao, X.; Wang, Z.; Fang, J.; Li, X. Planta Med. 2002, 68, 237-243. 
23. Ebringerova, A.; Kardosova, A.; Hromadkova, Z.; Malovikova, A.; Hribalova, V. Int. J. Biol. Macromol. 2002, 30, 1-6.

24. Han, S. B.; Park, S. H.; Lee, K. H.; Lee, C. W.; Lee, S. H.; Kim, H. C.; Kim, Y. S.; Lee, H. S.; Kim, H. M. Int. Immunopharmacol. 2001, 1, 1969-1978.

25. Stein, G. M.; Edlund, U.; Pfuller, U.; Bussing, A.; Schietzel, M. Anticancer Res. 1999, 19, 39073914.

26. Park, J. I.; Shim, J. K.; Do, J. W.; Kim, S. Y.; Seo, E. K.; Kwon, H. J.; Lee, T. K.; Kim, J. K.; Choi, D. Y.; Kim, C. H. Glycoconjugate J. 1999, 16, 247-252.

27. Sakurai, M. H.; Matsumoto, T.; Kiyohara, H.; Yamada, H. Immunology 1999, 97, 540-547.

28. Takemoto, N.; Kiyohara, H.; Maruyama, H.; Komatsu, Y.; Yamada, H.; Kawamura, H. Int. J. Immunopharmacol. 1994, 16, 919-929.

29. Dourado, F.; Barros, A.; Mota, M.; Coimbra, M. A.; Gama, F. M. J. Agric. Food Chem. 2004, 52, 13641370.

30. Dubois, M.; Gilles, K. A.; Hamilton, J. K.; Rebers, P. A.; Smith, F. Anal. Chem. 1956, 28, 350-356.

31. Selvendran, R. R.; March, J. F.; Ring, S. G. Anal. Biochem. 1979, 96, 282-292.

32. Ciucanu, I.; Kerek, F. Carbohydr. Res. 1984, 131, 209217.

33. Isogai, A.; Ishizu, A.; Nakano, J. Carbohydr. Res. 1985, 138, 99-108.

34. Lindberg, B.; Lönngren, J. Methods Enzymol. 1978, 50, 3 33.

35. Coimbra, M. A.; Delgadillo, I.; Waldron, K. W.; Selvendran, R. R. In Modern Methods of Plant Analysis; Linskens, H. F., Jackson, J. F., Eds.; Springer: Berlin, 1996; Vol. 17, pp 19-44.

36. Harris, P. J.; Henry, R. J.; Blakeney, A. B.; Stone, B. A. Carbohydr. Res. 1984, 127, 59-73.

37. Sweet, D. P.; Shapiro, R. H.; Albersheim, P. Carbohydr. Res. 1975, 40, 217-225.

38. Selvendran, R. R.; O’Neill, M. A. Methods Biochem. Anal. 1987, 32, 25-153.
39. Pilnik, W.; Voragen, A. G. J. In The Biochemistry of Fruits and Their Products; Hulme, A. C., Ed.; Academic: New York, 1970; Vol. 1, p 53.

40. Duan, J.; Wang, X.; Dong, Q.; Fang, J.-n; Li, X. Carbohydr. Res. 2003, 338, 1291-1297.

41. Yamada, H.; Kiyohara, H.; Cyong, J.-C.; Kojima, Y.; Kumazawa, Y.; Otsuka, Y. Planta Med. 1984, 50, 163 167.

42. Yamada, H.; Ohtani, K.; Kiyohara, H.; Cyong, J. C.; Otsuka, Y.; Ueno, Y.; Omura, S. Planta Med. 1985, 2, 121-125.

43. Stevens, B. J. H.; Selvendran, R. R. Phytochemistry 1980 19, 559-561.

44. Oechslin, R.; Lutz, M. V.; Amadò, R. Carbohydr. Polym. 2003, 51, 301-310.

45. Jacobs, D. M.; Morrison, D. C. J. Immunol. 1977, 118, 2127.

46. Butler, T.; Smith, E.; Hammarstrom, L.; Moller, G. Infect. Immun. 1977, 16, 449-455.

47. Beutler, B.; Cerami, A. Annu. Rev. Immunol. 1989, 7, 625655.

48. Moore, K. W.; O'Garra, A.; de Waal, M. R.; Vieira, P.; Mosmann, T. R. Annu. Rev. Immunol. 1993, 11, 165-190.

49. Han, S. B.; Kim, Y. H.; Lee, C. W.; Park, S. M.; Lee, H. Y.; Ahn, K. S.; Kim, I.-H.; Kim, H. M. Immunopharmacology 1998, 40, 39-48.

50. Jeon, Y. J.; Han, S. B.; Ahn, K. S.; Kim, H. M. Immunopharmacology 1999, 43, 1-9.

51. Jeon, Y. J.; Han, S. B.; Ahn, K. S.; Kim, H. M. Immunopharmacology 2000, 43, 275-284.

52. Cunningham-Rundles, C. J. Clin. Immunol. 1989, 9, 22-33.

53. Burrows, P. D.; Cooper, M. D. Adv. Immunol. 1997, 65, 245-276.

54. LeMaoult, J.; Szabo, P.; Weksler, M. E. Immunol. Rev. 1997, 160, 115-126.

55. Weksler, M. E.; Szabo, P. In Clinical Immunology Principles and Practice; Rich, R. R., Fleisher, T. A., Sherare, W. T., Kotzin, B. L., Schroeder, A., Eds.; Mosby: New York, 2001; pp, 2001 41.1-41.8.

56. Das, U. N. Crit. Care. 2000, 4, 290-296. 